\title{
ANALISIS INDEKS KERAPATAN VEGETASI UNTUK IDENTIFIKASI KEJADIAN DAN POTENSI PUTING BELIUNG DI WILAYAH KABUPATEN KLATEN
}

\section{ANALYSIS OF VEGETATION RATE INDEX FOR IDENTIFICATION OF THE EVENT AND POTENTIAL OF PUTING BELIUNG IN THE REGION OF KLATEN DISTRICT}

\author{
Zauyik Nana Ruslana ${ }^{1 *}$ dan Sulistiyowati ${ }^{2}$ \\ 1, 2 Stasiun Klimatologi Klas I Semarang \\ *E-mail: aziexzazak@gmail.com \\ Naskah masuk: 4 Juni 2020, Naskah diperbaiki: 17 Juli 2020, Naskah diterima: 20 Juli 2020
}

\section{ABSTRAK}

Dengan melakukan analisa citra landsat 8 yaitu Citra Satelit Landsat 8 OLI/TIRS yaitu berupa citra yang diperoleh dari USGS (United State Geological Survey) dengan pengolahan pertama dengan software ENVI untuk meningkatkan ketajaman dan kejelasan citra satelit, kemudian dilakukan pengolahan dengan ArcGIS 10.4 untuk menghasilkan peta NDVI dengan dua klasifikasi yaitu klasifikasi kerapatan dan vegetasi serta titik kejadian puting beliung di wilayah Kabupaten Klaten sesuai hasil pengolahan citra satelit Landsat 8 menjadi peta NDVI didapat bahwa di hampir seluruh wilayah Kabupaten Klaten lebih sedikit vegetasi dengan kerapatan tinggi, yang lebih banyak adalah lahan terbuka seperti sawah/ladang dan pemukiman penduduk. Kejadian puting beliung di wilayah Kabupaten Klaten berdasarkan data tahun 2018-2019 terjadi pada bulan Desember-April. Dengan semakin sedikitnya vegetasi yang kerapatannya tinggi dan semakin meningkatnya pemukiman penduduk dan lahan terbuka, maka potensi puting beliung akan semakin meningkat selain karena faktor lain seperti suhu udara, tekanan udara dan awan kumulonimbus. Manfaat yang diperoleh adalah dapat sebagai pertimbangan dalam membangun dan penataan infrastruktur yang lebih hijau dan berkesinambungan, serta sebagai mitigasi dan adaptasi terhadap wilayah yang paling rawan terdampak puting beliung di Kabupaten Klaten.

Kata kunci:wind shear, vortex, NDVI, Puting Beliung, Landsat 8
ABSTRACT

By analyzing Landsat 8 imagery, Landsat 8 OLI ITIRS satellite imagery in the form of images obtained from the USGS (United State Geological Survey) with the first processing with ENVI software to improve the sharpness and clarity of satellite imagery, then processing with ArcGIS 10.4 to produce maps NDVI with two classifications, namely density and vegetation classification, and the point of occurrence of puting beliung in the Klaten Regency. According to the Landsat 8 satellite image processing being an NDVI map, it is found that in almost all regions of Klaten Regency there is less vegetation with high density, which is more open land such as rice fields/fields and residential areas. The occurrence of a puting beliung in the Klaten Regency region based on data from 2018-2019 occurred in DecemberApril. With the lack of vegetation with high density and increasing population of settlements and open land, the potential for puting beliung will increase in addition to other factors such as air temperature, air pressure and Cumulonimbus Clouds. The benefits gained can be taken into consideration in building and structuring a greener and more sustainable infrastructure, as well as mitigating and adapting to areas most vulnerable to tornadoes in Klaten Regency.

Keywords: ENVI, OLI/TIRS, NDVI, Puting Beliung, Landsat 8 


\section{Pendahuluan}

Secara topografi Kabupaten Klaten terletak di antara Gunung Merapi dan Pegunungan Seribu Dengan ketinggian antara 75 hingga 160 meter Di Atas Permukaan Laut yang terbagi menjadi wilayah Lereng Gunung Merapi di bagian utara areal miring, wilayah datar dan berbukit di bagian selatan. Dari ketinggiannya, Kabupaten Klaten terdiri dari dataran dan pegunungan yang berada pada ketinggian bervariasi, yaitu 9,72 persen terletak di ketinggian 0-100 meter dari permukaan air laut. 77,52 persen terletak di ketinggian 100-500 meter dari permukaan air laut dan 12,76 persen terletak di ketinggian 500-1.000 meter dari permukaan air laut. Sebagian besar wilayah kabupaten ini adalah dataran rendah dan tanah bergelombang. Secara geografis Kabupaten Klaten terletak antara $110^{\circ} 26^{\prime} 14^{\prime \prime}$ - $110^{\circ} 47^{\prime}$ 51'BT dan $7^{0} 32^{\prime}$ $19^{\prime \prime}$ - $7^{0} 48^{\prime} 33^{\prime \prime}$ LS. Kabupaten Klaten secara umum berbatasan dengan beberapa wilayah kabupaten yaitu Sebelah Utara: Kabupaten Boyolali, Sebelah Timur: Kabupaten Sukoharjo, Sebelah Selatan: Kabupaten Gunung kidul (DIY), Sebelah Barat: Kabupaten Sleman (DIY) [1]. Secara klimatologis, Kabupaten Klaten terpengaruh Monsun Asia dan Australia sehingga memiliki dua musim yaitu musim hujan dan musim kemarau, dengan normal curah hujan (1981-2010) tahunan berkisar antara 1438-1945 mm.

Salah satu kejadian cuaca ekstrem adalah puting beliung yang memberikan dampak yang merusak seperti kerusakan bangunan, merobohkan pohon, hingga dapat menimbulkan korban jiwa dan harta. Bila dibandingkan dengan banjir, puting beliung lebih murni disebabkan oleh faktor alam [7]. Salah satu wilayah di Provinsi Jawa Tengah dengan tingkat kejadian puting beliung yang cukup tinggi adalah Kabupaten Klaten, dimana sebagian besar wilayahnya adalah dataran rendah sangat berpengaruh terhadap potensi puting beliung. Dampak perubahan lingkungan seperti vegetasi, perubahan penggunaan lahan, bertambahnya jumlah penduduk ikut berpengaruh dalam proses terbentuknya puting beliung yang berasal dari awan konvektif.

Puting beliung adalah sebutan masyarakat terhadap fenomena angin kencang yang berputar (vortex), dan umumnya terjadi bersamaan dengan curah hujan dengan intensitas tinggi [12]. Puting Beliung datang secara tiba-tiba, dalam beberapa menit, puting beliung terbentuk dan mulai menyebabkan kehancurannya [8]. Angin puting beliung mempunyai kecepatan rata-rata $30-40$ knots berasal dari awan kumulonimbus $(\mathrm{Cb})$ yaitu awan yang bergumpal, berwarna abu-abu gelap dan menjulang tinggi [9]. Fenomena ini bersifat lokal, mencakup area antara 5-10 kilometer. Periode hidupnya sangat singkat, yaitu sekitar 3-5 menit, mulai dari tumbuh hingga punahnya. Jenis angin ini di Indonesia kadang dikenal juga dengan istilah angin Puyuh, Lesus (Jawa), Sirit Batara (Sunda). Mengukur kekuatan dan dampak puting beliung dapat menggunakan skala Fujita [10], skala tersebut dapat dilihat pada Tabel 2 .

Tabel 2. Skala Fujita [10].

\begin{tabular}{|c|c|c|}
\hline Kategori & $\begin{array}{c}\text { Kecepatan } \\
\text { Angin }\end{array}$ & Tingkat Kerusakan \\
\hline F0 (Lemah) & $\begin{array}{l}64-116 \\
\mathrm{Km} / \mathrm{Jam} \\
40-72 \mathrm{mph}\end{array}$ & $\begin{array}{l}\text { Kerusakan pada } \\
\text { atap rumah }\end{array}$ \\
\hline F1 (Sedang) & $\begin{array}{l}117-181 \\
\mathrm{Km} / \mathrm{Jam} \\
73-112 \mathrm{mph}\end{array}$ & $\begin{array}{l}\text { Atap rumah } \\
\text { terangkat }\end{array}$ \\
\hline F2 (Kuat) & $\begin{array}{l}182-253 \\
\mathrm{Km} / \mathrm{Jam} 113- \\
157 \mathrm{mph}\end{array}$ & $\begin{array}{l}\text { Atap rumah } \\
\text { terangkat dengan } \\
\text { semua kuda- } \\
\text { kudanya }\end{array}$ \\
\hline $\begin{array}{c}\text { F3 (Sangat } \\
\text { Kuat) }\end{array}$ & $\begin{array}{l}254-332 \\
\text { Km/Jam 158- } \\
206 \text { mph }\end{array}$ & $\begin{array}{l}\text { Atap dan dinding } \\
\text { rumah hancur, } \\
\text { pecah dan lepas } \\
\text { dari rangka } \\
\text { dasarnya }\end{array}$ \\
\hline F4 (Dahsyat) & $\begin{array}{l}333-419 \\
\text { Km/Jam } \\
207-260 \mathrm{mph}\end{array}$ & $\begin{array}{l}\text { Rumah beton rata } \\
\text { tanah, bangunan } \\
\text { berpondasi kurang } \\
\text { kuat terlempar jauh }\end{array}$ \\
\hline $\begin{array}{l}\text { F5 (Luar } \\
\text { Biasa) }\end{array}$ & $\begin{array}{l}420-512 \\
\mathrm{Km} / \mathrm{Jam} \\
263-318 \mathrm{mph}\end{array}$ & $\begin{array}{l}\text { Pondasi paling } \\
\text { kuat sekalipun } \\
\text { terangkat dan } \\
\text { bergeser }\end{array}$ \\
\hline
\end{tabular}

Vegetasi sebagai penyusun lahan mempunyai jenis yang sangat beranekaragam. Kumpulan dari berbagai vegetasi yang beraneka ragam ini akan menghasilkan tingkat kerapatan vegetasi yang berbeda-beda pada tiap penggunaan lahan di suatu daerah.

Adapun tujuan penelitian yang dilakukan dari penelitian ini adalah Untuk mendapatkan nilai indeks vegetasi area pemukiman di wilayah Kabupaten Klaten dengan menggunakan metode NDVI, serta potensinya terhadap kejadian puting beliung terhadap perubahan vegetasi dan kerapatannya. Manfaat yang diperoleh :

1. Dapat sebagai pertimbangan dalam pembangunan infrastruktur yang lebih hijau dalam penataan lingkungan perumahan, hutan lindung, pertanian, perkebunan, perkotaan yang ramah lingkungan dan berkelanjutan.

2. Mitigasi pra dan pasca bencana angin kencang dan puting beliung. 
3. Pembelajaran bagi masyarakat tentang dampak, mengatasi dan adaptasi terhadap potensi puting beliung.

\section{Metode Penelitian}

Tingkat kerapatan vegetasi dapat dikaji melalui penggunaan teknologi yang saat ini terus berkembang. Vegetasi memiliki ciri khas spektral yang unik sehingga dapat dianalisis dengan berbagai cara untuk mendapatkan indeks yang mewakili kondisi dari vegetasi. Teknologi tersebut adalah teknologi penginderaan jauh (remote sensing) dan sistem informasi geografis (SIG). Metode pengukuran vegetasi menggunakan citra satelit memanfaatkan reflektansi dari fitur lanskap [2]. Tinggi rendahnya suatu kerapatan vegetasi dapat diketahui dengan menggunakan NDVI (Normalized Difference Vegetation Index), yang merupakan sebuah transformasi citra penajaman spektral untuk menganalisa hal-hal yang berkaitan dengan vegetasi [3].

Identifikasi objek dengan menggunakan teknologi penginderaan jauh dilaksanakan dengan beberapa pendekatan antara lain; karakteristik spektral citra, visualisasi, floristik, geografi dan phsygonomik [4], Khususnya pada sistem satelit (citra satelit) lebih banyak didasarkan atas karakteristik spektral. Objek yang berbeda akan memberikan pantulan spektral yang berbeda pula, bahkan obyek yang sama dengan kondisi dan kerapatan yang berbeda akan memberikan nilai spektral yang berbeda.

Indeks vegetasi merupakan suatu algoritma yang diterapkan terhadap citra satelit, untuk menonjolkan aspek kerapatan vegetasi ataupun aspek lain yang berkaitan dengan kerapatan, misalnya biomassa, Leaf Area Index (LAI), konsentrasi klorofil. Atau lebih praktis, indeks vegetasi adalah merupakan suatu transformasi matematis yang melibatkan beberapa saluran sekaligus untuk menghasilkan citra baru yang lebih representatif dalam menyajikan aspekaspek yang berkaitan dengan vegetasi [5]. Selanjutnya dikatakan [6] bahwa 3 metode indeks vegetasi ada beberapa macam antara lain; NDVI (Normalized Difference Vegetation Index), GI (Green Indeks) dan WI (Wetness Index). Dalam analisa ini hanya menggunakan metode NDVI. Informasi data kerapatan vegetasi, luas lahan, dan keadaan di lapangan dapat dideteksi dengan penginderaan jauh yaitu menggunakan citra satelit.Perubahan kerapatan vegetasi ini dapat dipantau menggunakan citra satelit. Dalam melakukanya digunakan citra satelit, yaitu Landsat 8 OLI/TIRS. Dalam sejarahnya teknologi satelit penginderaan jauh dipelopori oleh NASA Amerika Serikat dengan diluncurkannya satelit sumber daya alam yang pertama, yang disebut ERTS-1 (Earth Resources Technology Satellite) pada tanggal 23 Juli 1972, menyusul ERTS-2 pada tahun 1975, satelit ini membawa sensor RBV (Retore Beam Vidcin) dan MSS ( Scanner System) yang mempunyai resolusi pasial 80 × $80 \mathrm{~m}$. Satelit ERTS1, ERTS-2 yang kemudian setelah diluncurkan berganti nama menjadi Landsat 1, Landsat 2, diteruskan dengan seri-seri berikutnya, yaitu Landsat 3, 4, 5, 6,7 dan terakhir adalah Landsat 8 [11].

Indeks vegetasi adalah besaran nilai kehijauan vegetasi yang diperoleh dari pengolahan sinyal digital data nilai kecerahan (brightness) beberapa kanal data sensor satelit. Untuk pemantauan vegetasi, dilakukan proses perbandingan antara tingkat kecerahan kanal cahaya merah (red) panjang cahaya inframerah dekat (near infrared). Fenomena penyerapan cahaya merah oleh klorofil dan pemantulan cahaya inframerah dekat oleh jaringan mesofil yang terdapat pada daun akan membuat nilai kecerahan yang diterima sensor satelit pada kanal-kanal tersebut akan jauh berbeda. Pada daratan non-vegetasi, termasuk diantaranya wilayah perairan, pemukiman penduduk, tanah kosong terbuka, dan wilayah dengan kondisi vegetasi yang rusak, tidak akan menunjukkan nilai rasio yang tinggi (minimum). Sebaliknya pada wilayah bervegetasi sangat rapat, dengan kondisi sehat, perbandingan kedua kanal tersebut akan sangat tinggi (maksimum). Nilai perbandingan kecerahan kanal cahaya merah dengan cahaya inframerah dekat atau NIR/RED, adalah nilai suatu indeks vegetasi (yang sering disebut "simple ratio") yang sudah tidak dipakai lagi. Hal ini disebabkan karena nilai dari rasio NIR/RED akan memberikan nilai yang sangat besar untuk tumbuhan yang sehat. Oleh karena itu, dikembangkanlah suatu algoritma indeks vegetasi yang baru dengan normalisasi, yaitu NDVI (Normalized Difference Vegetation Index). NDVI adalah perbedaan nilai reflektansi merah dekat dan inframerah yang dinormalisasi karena pantulan.

Secara khusus adalah :

$$
N D V I=\frac{(N I R-R E D)}{(N I R+R E D)}
$$

Keterangan:

NIR = Band yang memiliki panjang gelombang inframerah dekat (band 5) RED = Pantulan pada band merah (band 4) yang terlihat 
Persamaan tersebut akan menghasilkan rentang nilai -1 hingga 1 . Nilai -1 menunjukan objek awan, salju, air, non-vegetasi. Sedangkan, nilai 1 menunjukan objek vegetasi. Adapun klasifikasinya yaitu tersaji dalam tabel 1 , yang menunjukkan nilai range index NDVI untuk klasifikasi kerapatan dan klasifikasi vegetasi .

Tabel 1. Klasifikasi NDVI [13]

\begin{tabular}{lll}
\hline $\begin{array}{l}\text { Rentang } \\
\text { Klasifikasi }\end{array}$ & Kerapatan & Vegetasi \\
\hline$-1-0$ & $\begin{array}{l}\text { Awan, Badan } \\
\text { Air, } \\
\text { Nonvegetasi } \\
\text { Vegetasi } \\
\text { Jarang }\end{array}$ & - \\
$0-0,25$ & $\begin{array}{l}\text { Pemukiman, } \\
\text { Lahan } \\
\text { Kosong } \\
\text { Sakup Rapat } \\
0,25-0,55\end{array}$ & $\begin{array}{l}\text { Sawah, } \\
\text { Tegalan } \\
\text { Sawah, } \\
\text { Semak }\end{array}$ \\
$0,55-0,78$ & Rapat & $\begin{array}{l}\text { Belukar } \\
\text { Hutan }\end{array}$ \\
\hline
\end{tabular}

Dalam penelitian ini data yang digunakan yaitu Citra Satelit Landsat 8 OLI/TIRS yaitu berupa citra yang diperoleh dari USGS (United State Geologycal Survey) (https://earthexplorer.usgs.gov/) yang terletak di Path 120 Row 65 , Kabupaten Klaten berada pada wilayah citra satelit tersebut. Data citra satelit yang dipilih adalah yang bebas gangguan seperti awan, noise dari bulan Januari-Desember 2018. Citra satelit landsat 8 yang dipilih adalah bulan September 2018 dengan tingkat gangguan awan dan noise yang rendah. Berikut adalah proses layer stacking dan penajaman citra landsat-8 :

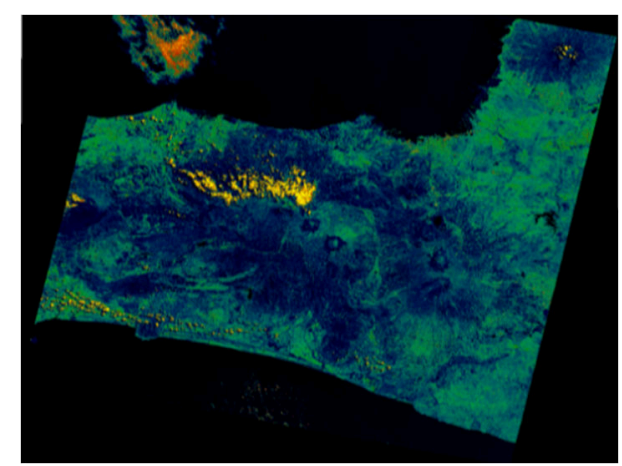

Gambar 1. Citra Jawa Tengah hasil dari layer Stacking satelit Landsat 8 (warna)

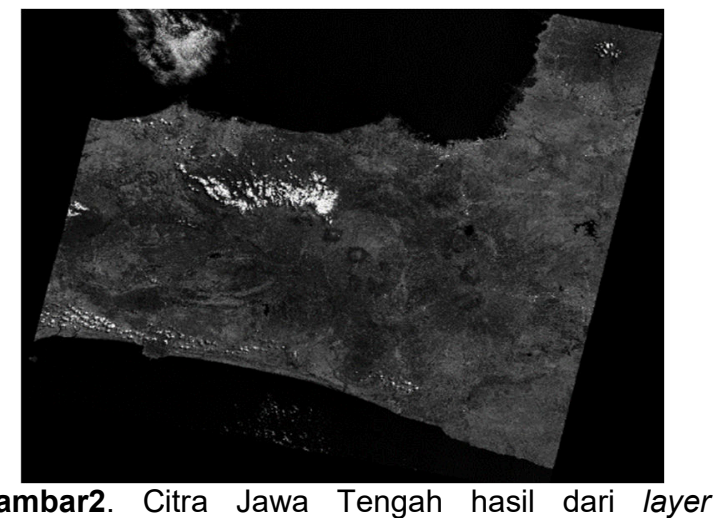

Stacking satelit Landsat 8 (grayscale)

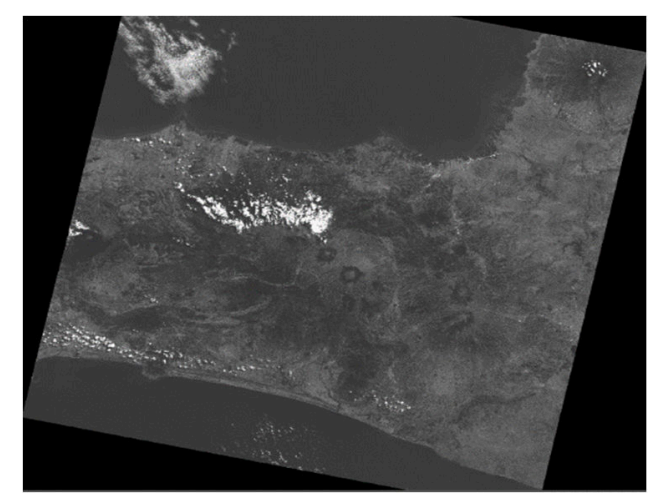

Gambar3. Citra Jawa Tengah hasil penajaman satelit Landsat 8 (grayscale)

Pada gambar 1-2 merupakan hasil layer stacking dari citra satelit Landsat 8 pada band 1-8. Sedangkan pada gambar 3 adalah citra satelit Landsat 8 hasil penajaman dengan software ENVI. Setelah melakukan layer stacking dan penajaman citra satelit Landsat 8 adalah dengan menghitung indeks NDVI di Arcgis 10.4 untuk menghasilkan perbedaan gradasi warna yang berbeda sesuai dengan klasifikasi NDVI. Kemudian dipetakan titik-titik kejadian puting beliung di wilayah Kabupaten Klaten, sehingga akan menghasilkan potensi kejadian puting beliung berdasarkan tingkat kerapatan dan vegetasi. Alur kerja umum dalam pengolahan Landsat 8 untuk menjadi citra klasifikasi NDVI ditunjukkan pada gambar 4 (a). 


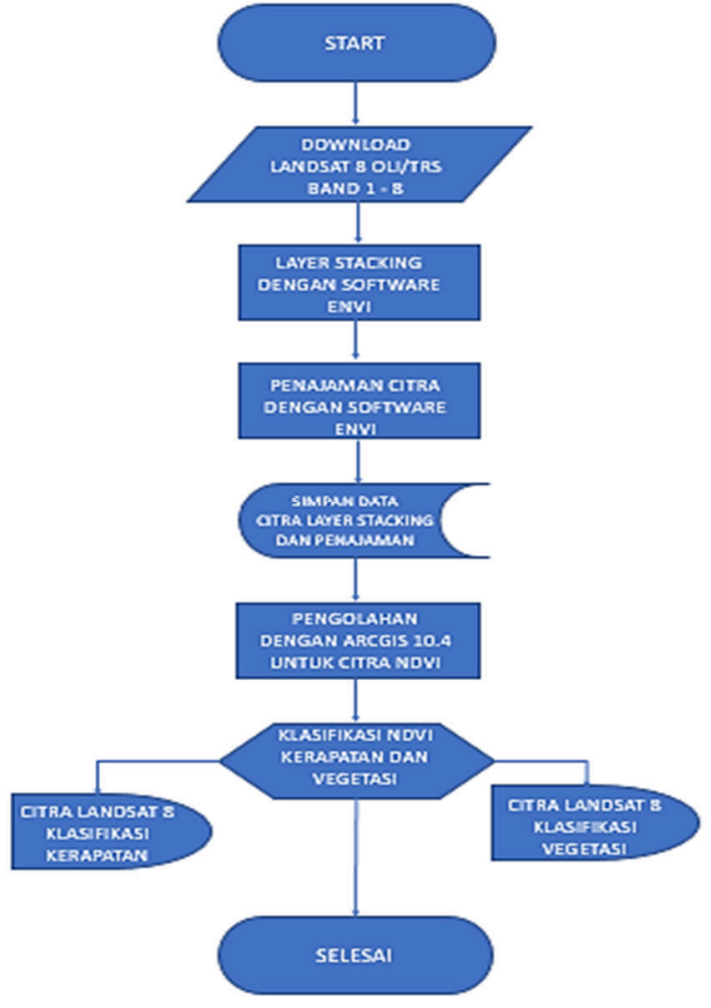

(a)

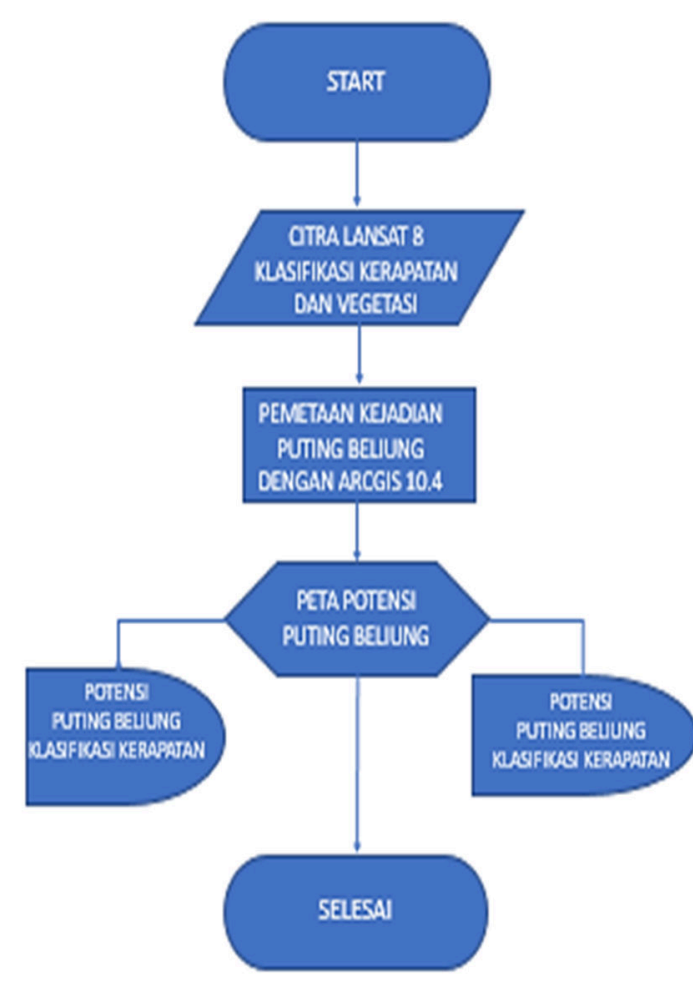

(b)

Gambar 4. (a) Alur kerja/flowchart umum pengolahan Landsat 8 dalam klasifikasi NDVI, (b) Alur kerja/flowchart umum pengolahan Landsat 8 klasifikasi NDVI untuk kerapatan dan vegetasi dengan titik kejadian puting beliung.

Pada gambar 4 (b), merupakan alur kerja umum pengolahan Landsat 8 yang sudah menjadi peta NDVI berdasarkan klasifikasi kerapatan dan vegetasi dengan titik-titik kejadian puting beliung di wilayah Kabupaten Klaten berdasarkan data kejadian tahun 2018.

\section{Hasil dan Pembahasan}

Dari beberapa penelitian masih sedikit yang menghubungkan tentang analisis indeks kerapatan vegetasi dengan potensi puting beliung, seperti pada tulisan [15] hanya menyatakan Berdasarkan peta distribusi bencana angin ribut, angin ribut banyak terjadi di beberapa provinsi yang ada di Pulau Jawa yaitu Provinsi Jawa Barat, Jawa Tengah dan Jawa Timur.Dan hanya melakukan penelitian tentang kajian bencana angin rebut dan mitigasi bencananya. Pada penelitian lain [16] membahas upaya untuk mengidentifikasi kondisi awal kejadian puting beliung atau kejadian seperti tornado yang terjadi di kota Pangkalpinang pada 9 Januari 2008. Dan hanya dengan pengamatan permukaan dan Analisa dari citra satelit dengan SATAID.

Penelitian-penelitian lain indeks vegetasi lebih banyak hanya membahas tentang perapatan dan pemetaan kondisi wilayah dan vegetasi. Maka dari itu penulis berusaha untuk melakukan penelitian dengan pembahasan dengan dilakukan pengolahan citra satelit Landsat 8 OLI/TIRS dengan menggunakan Arcgis 10.4 maka akan menghasilkan 2 jenis peta klasifikasi NDVI yaitu klasifikasi kerapatan dan klasifikasi vegetasi. Yaitu pada gambar 5 dan 6. Pada gambar 5 klasifikasi kerapatan untuk wilayah Kabupaten Klaten lebih dominan pada vegetasi jarang pada rentang klasifikasi $0-0,20$ dan cukup rapat di rentang klasifikasi $0,25-0,55$. 

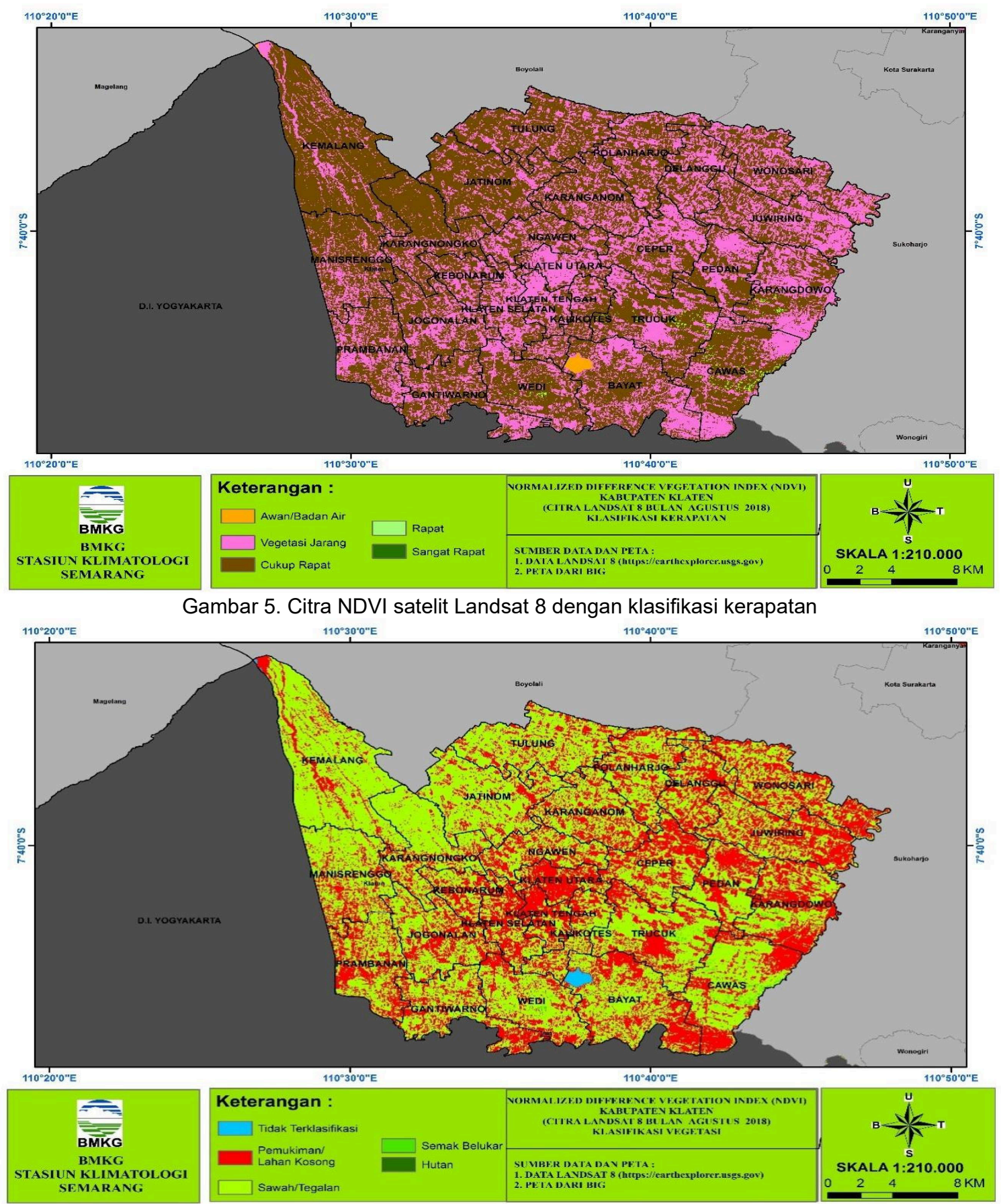

Gambar 6. Citra NDVI satelit Landsat 8 dengan klasifikasi vegetasi.

Untuk gambar 6 klasifikasi vegetasi untuk wilayah Kabupaten Klaten dominan pemukiman/lahan kosong pada rentang klasifikasi $0-0,20$ dan sawah/tegalan pada rentang klasifikasi $0,25-0,55$. Dengan dua peta tersebut maka untuk wilayah Kabupaten Klaten tingkat kerapatan vegetasi sudah berkurang dan pengaruh penggunaan lahan atau wilayah untuk pertanian dan perumahan lebih luas penggunaannya. Hal ini berpengaruh pada keseringan jumlah kejadian puting beliung, yang berhubungan dengan luasnya lahan terbuka. Sebagai gambaran, berikut peta kejadian puting beliung di beberapa wilayah Kecamatan di Kabupaten Klaten pada tahun 2018 pada gambar 7 dan 8 serta tahun 2019 pada gambar 9 dan 10 . 


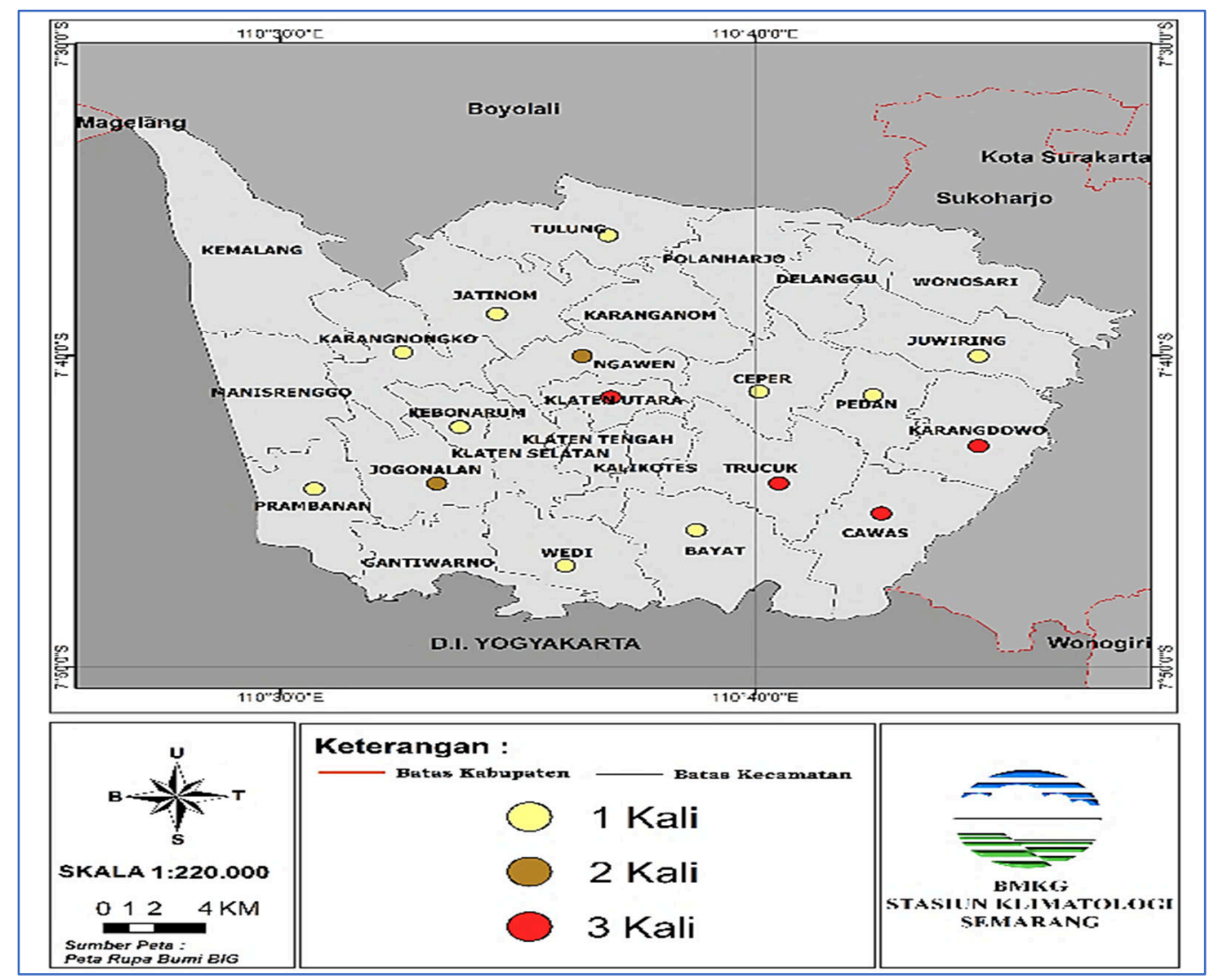

Gambar 7. Peta titik kejadian puting beliung di Kabupaten Klaten Tahun 2018.

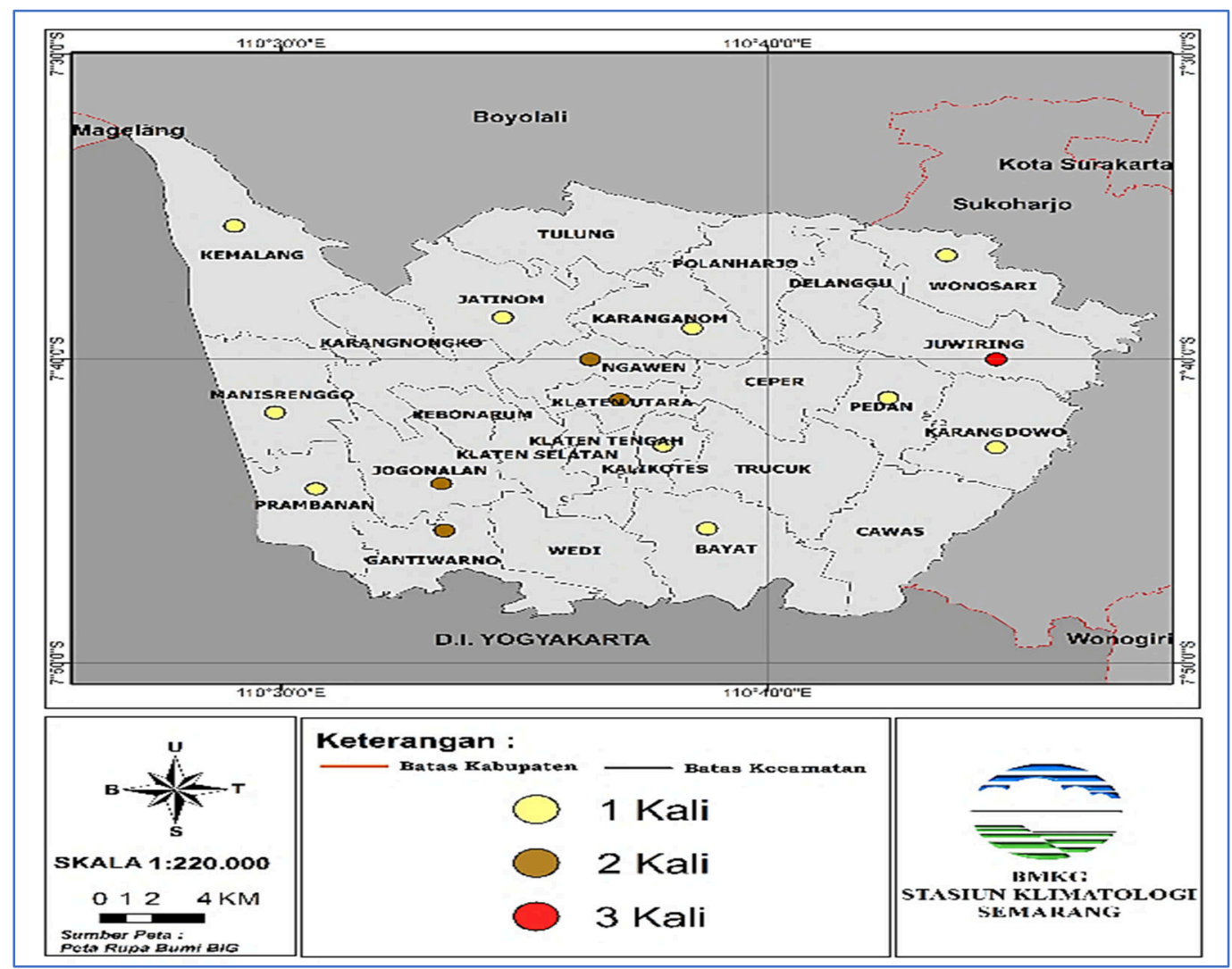

Gambar 8. Peta titik kejadian puting beliung di Kabupaten Klaten Tahun 2019. 
Dapat dijelaskan bahwa kejadian puting beliung pada tahun 2018 dan 2019 di wilayah Kabupaten Klaten hampir merata. Untuk rincian detail kejadian untuk tahun 2018 adalah kejadian puting beliung 3 kali meliputi Kecamatan Trucuk, Klaten Utara, Cawas dan Karangdowo, kejadian puting beliung 2 kali meliputi wilayah Kecamatan Ngawen dan Jogonalan, kejadian puting beliung 1 kali meliputi Wilayah Kecamatan Tulung, Prambanan, Kebonarum, Karangnongko, Ceper, Pedan, Wedi, Bayat, Juwiring dan Jatinom, dapat dilihat pada tabel 3. Kejadian puting beliung pada Tahun 2018 di Kabupaten Klaten lebih sering terjadi pada periode musim hujan yaitu Desember-April, sedangkan saat musim kemarau tidak ada.

Untuk rincian detail kejadian untuk tahun 2019 adalah kejadian puting beliung 3 kali meliputi Kecamatan Juwiring, kejadian puting beliung 2 kali meliputi wilayah Kecamatan Klaten Utara, Jogonalan, Ngawen dan Gantiwarno, kejadian puting beliung 1 kali meliputi Wilayah Kecamatan Prambanan, Karangdowo, Pedan, Bayat, Jatinom, Karanganom, Kalikotes, Manisrenggo, Wonosari dan Pemalang dapat di lihat pada tabel 4. Kejadian puting beliung Tahun 2019 di Kabupaten Klaten untuk periode musim kejadiannya sama denga Tahun 2018 yaitu pada musim hujan.

Tabel 3. Kejadian puting beliung tahun 2018 [14]

\begin{tabular}{|c|c|c|c|c|c|c|c|}
\hline \multirow{2}{*}{ KEC } & \multicolumn{6}{|c|}{ BLN } & \multirow{2}{*}{ JML } \\
\hline & JAN & FEB & MAR & $A P R$ & $\begin{array}{l}\text { MEI - } \\
\text { NOV }\end{array}$ & DES & \\
\hline TRUCUK & 1 & 1 & & 1 & & & 3 \\
\hline TULUNG & & & 1 & & & & 1 \\
\hline KLATEN UTARA & 2 & & & 1 & & & 3 \\
\hline PRAMBANAN & 1 & & & & & & 1 \\
\hline CAWAS & 2 & & & 1 & & & 3 \\
\hline NGAWEN & 1 & & & & & 1 & 2 \\
\hline KEBONARUM & 1 & & & & & & $\mathbf{I}$ \\
\hline KARNGXONGKO & 1 & & & & NII & & 1 \\
\hline JOGONALAN & 1 & & & & & 1 & 2 \\
\hline CEPER & & 1 & & & & & 1 \\
\hline KARANGDOWO & & 1 & & 1 & & 1 & 3 \\
\hline PEDAN & & & & 1 & & & 1 \\
\hline WEDI & & & & 1 & & & 1 \\
\hline BAYAT & & & & 1 & & & 1 \\
\hline JUWIRING & & & & & & 1 & $\mathbf{1}$ \\
\hline JATINOM & & & & & & 1 & 1 \\
\hline
\end{tabular}

Tabel 4. Kejadian puting beliung tahun 2019 [14]

\begin{tabular}{|c|c|c|c|c|c|c|c|c|c|c|}
\hline \multirow{2}{*}{ No } & \multirow{2}{*}{ KEC } & \multicolumn{8}{|c|}{ BLY } & \multirow{2}{*}{ JIL } \\
\hline & & JAN & FEB & MLAR & $A P R$ & MEI -SEP & OKT & Nov & DES & \\
\hline 1 & KLATEN UTARA & 1 & & 1 & & & & & & 2 \\
\hline 2 & PRAMBANAN & & & 1 & & & & & & 1 \\
\hline 3 & JOGONALAN & & & 1 & & & & & 1 & 2 \\
\hline 4 & KARANGDOWO & 1 & & & & & & & & 1 \\
\hline 5 & PEDAN & 1 & & & & & & & & 1 \\
\hline 6 & BAYAT & & & 1 & & & & & & 1 \\
\hline 7 & JUTIRING & & 1 & 1 & & & & & 1 & 3 \\
\hline 8 & JATINOM & & & & & $\mathrm{N} I \mathrm{~L}$ & & NIL & 1 & 1 \\
\hline 9 & NGAWEN & 1 & & & & & & & 1 & 2 \\
\hline 10 & KARANGANOM & 1 & & & & & & & & 1 \\
\hline 11 & GANTTWARNO & 1 & & 1 & & & & & & 2 \\
\hline 12 & KALIKOTES & & 1 & & & & & & & 1 \\
\hline 13 & MANISRENGGO & & & 1 & & & & & & 1 \\
\hline 14 & WONOSARI & & & & 1 & & & & & 1 \\
\hline 15 & KEMALAVG & & & & & & 1 & & & 1 \\
\hline
\end{tabular}


Dari tabel 3 dan 4 tersebut hanya terjadi satu kali puting beliung bukan di periode DesemberApril di tahun 2019 yaitu wilayah Kecamatan Kemalang di bulan Oktober, saat musim peralihan Musim Kemarau ke Musim Hujan. Secara keseluruhan kejadian puting beliung di wilayah Kabupaten Klaten sebarannya hamper merata.

Untuk lebih jelas kejadian dan potensi puting beliung dengan membandingkan dengan tingkat kerapatan dan vegetasi dari citra Landsat 8 yaitu pada gambar 9 untuk tahun 2018 pada klasifikasi kerapatan vegetasinya sebaran titik-titik kejadian puting beliung 3 kali kejadian (warna titik biru) di wilayah Kecamatan Klaten Utara dan Trucuk dengan tingkat kerapatan vegetasi jarang (warna pink) sedangkan untuk Kecamatan Cawas dan Karangdowo dengan tingkat kerapatan vegetasinya cukup rapat (warna coklat tua). Kejadian puting beliung 2 kali kejadian (warna titik hijau) di wilayah Kecamatan Jogonalan dan Ngawen dengan tingkat kerapatan vegetasi jarang (warna pink). Sedangkan untuk 1 kali kejadian (warna titik pink coklat muda) di wilayah Kecamatan Prambanan, Jogonalan, wedi, Bayat, Ceper, Pedan dan Juwiring dengan tingkat kerapatan vegetasi jarang (warna pink), sedangkan Kecamatan Tulung, Jatinom dan Karangnongko dengan tingkat kerapatan cukup rapat (warna coklat tua).

Pada gambar 10 untuk kejadian puting beliung tahun 2018 dengan peta layer klasifikasi vegetasi dengan sebaran titik kejadian puting beliung 3 kali (warna biru) meliputi wilayah Kecamatan Trucuk dengan tingkat vegetasi banyak pemukiman/lahan kosong (warna merah), sedangkan di Kecamatan Cawas dan Karangdowo dengan tingkat vegetasi banyak sawah/tegalan (warna hijau muda). Untuk kejadian puting beliung 2 kali (warna titik hijau) meliputi wilayah Kecamatan Jogonalan dan Ngawen dengan tingkat vegetasi banyak pemukiman/lahan kosong (warna merah). Kejadian puting beliung 1 kali meliputi Kecamatan Juwiring, Pedan, Ceper, Kebonarum, Prambanan dan Wedi dengan tingkat vegetsi banyak pemukiman/lahan kosong (warna merah). Sedangkan Wilayah Kecamatan Karangnongko dan Jatinom dengan tingkat vegetasi banyak sawah/tegalan (warna hijau muda)

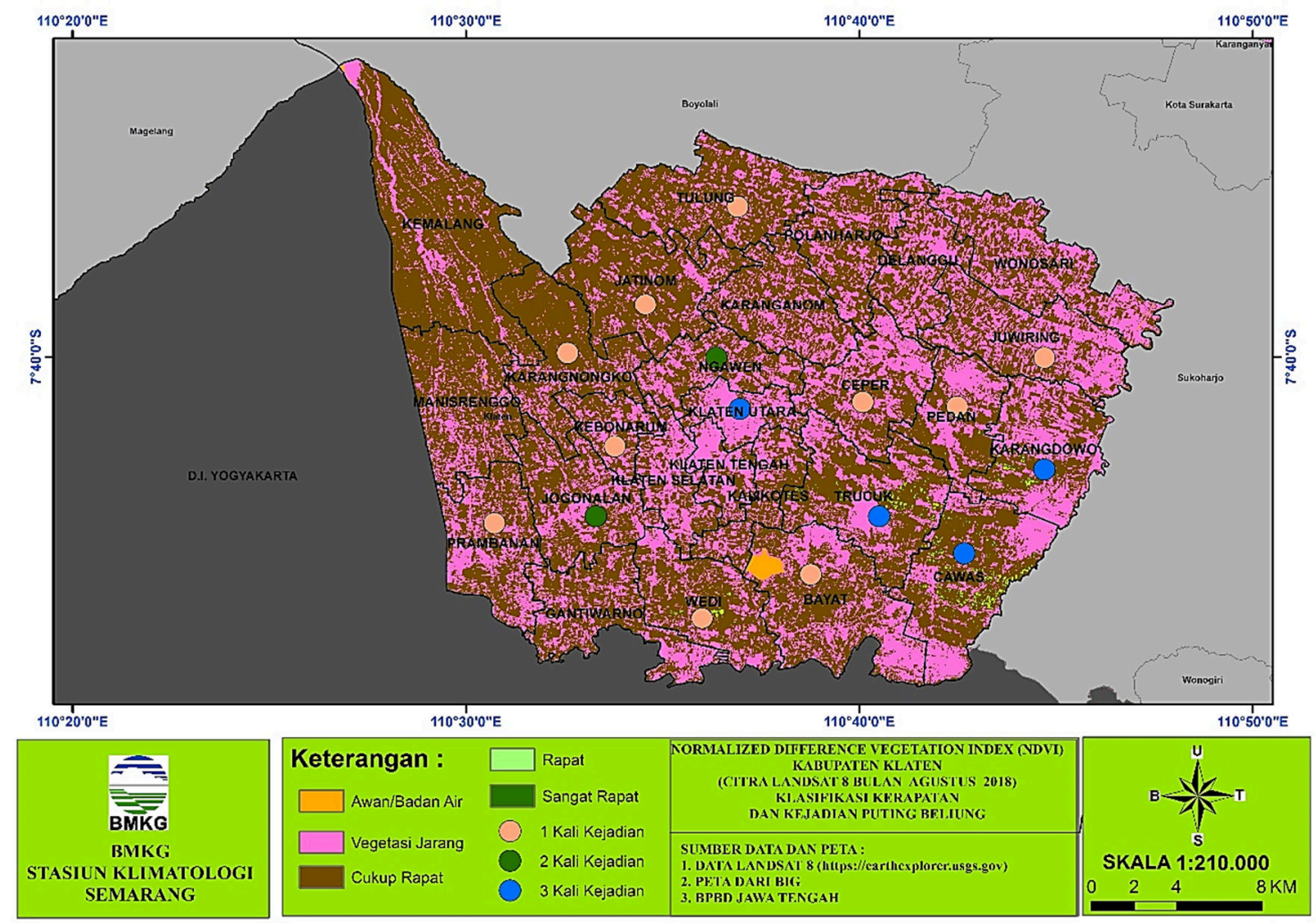

Gambar 9. Peta titik kejadian puting beliung layer dengan klasifikasi kerapatan di Kabupaten Klaten Tahun 2018. 


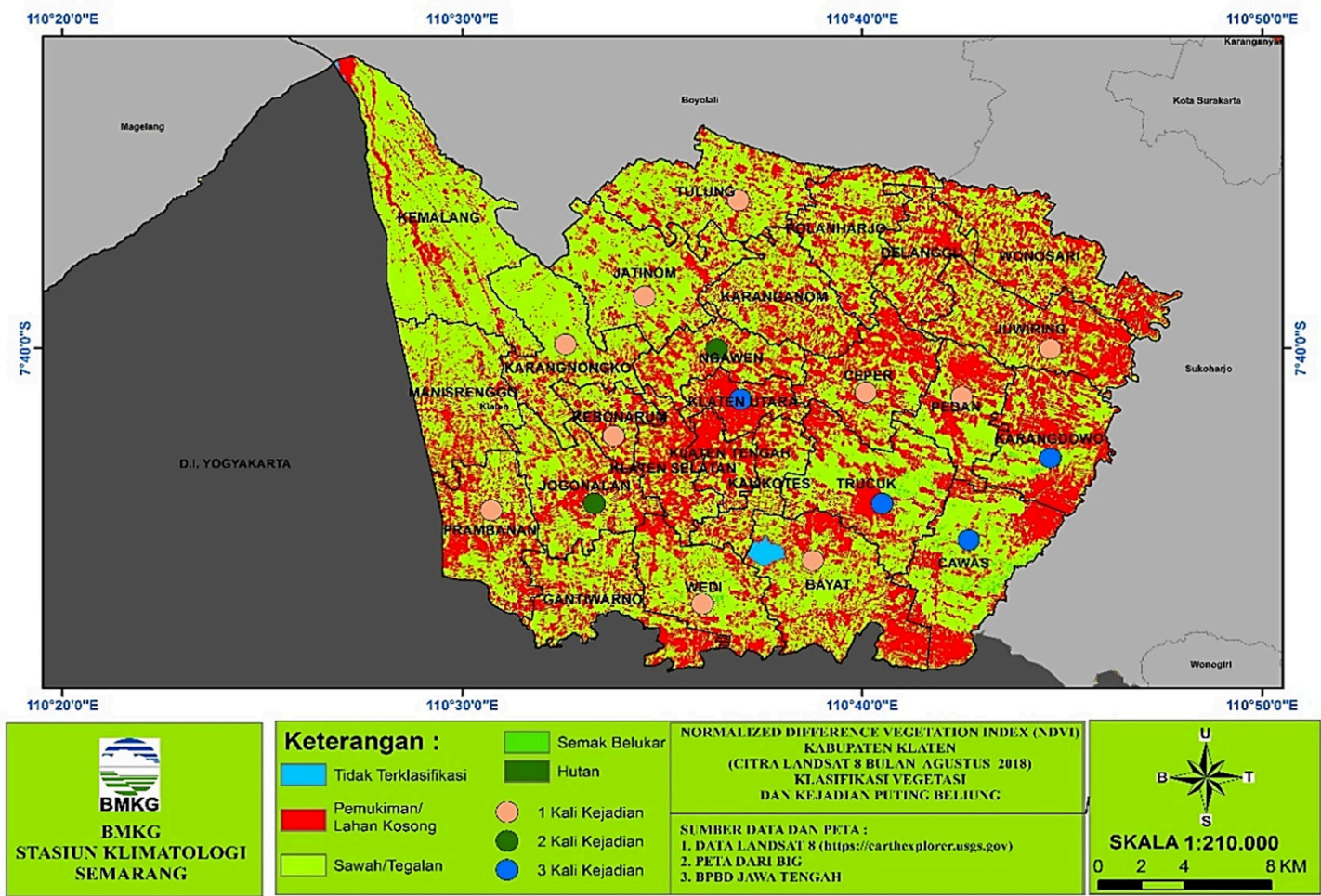

Gambar 10. Peta titik kejadian puting beliung layer dengan klasifikasi vegetasi di Kabupaten Klaten Tahun 2018.

Untuk Tahun 2019 pada gambar 11, perbandingan kejadian puting beliung dengan tingkat kerapatan, sebaran titik-titik kejadian puting beliung beliung 3 kali kejadian (warna titik biru) di wilayah Kecamatan Juwiring dengan tingkat kerapatan jarang (warna pink). Kejadian puting beliung 2 kali kejadian (warna titik hijau) di wilayah Kecamatan Jogonalan dan Klaten Utara dengan tingkat kerapatan vegetasi jarang (warna pink), untuk wilayah Kecamatan Ngawen dan Gantiwarno dengan tingkat kerapatan cukup rapat (warna coklat tua). Sedangkan untuk 1 kali kejadian (warna titik pink coklat muda) di wilayah Kecamatan Wonosari, Pedan, Manisrenggo, Prambanan, Karanganom, Klaten Tengah dan Bayat dengan tingkat kerapatan vegetasi jarang (warna pink), sedangkan Kecamatan Jatinom dan Kemalang dengan tingkat kerapatan cukup rapat (warna coklat tua).

Pada gambar 12 untuk kejadian puting beliung tahun 2019 dengan peta layer klasifikasi vegetasi dengan sebaran titik kejadian puting beliung 3 kali (warna biru) meliputi wilayah Kecamatan Juwiring dengan tingkat vegetasi banyak pemukiman/lahan kosong (warna merah). Untuk kejadian puting beliung 2 kali (warna titik hijau) meliputi wilayah Kecamatan Klaten Utara, Jogonalan dan Ngawen dengan tingkat vegetasi banyak pemukiman/lahan kosong (warna merah), sedangkan untuk wilayah Kecamatan Gantiwarno dengan tingkat vegetasi cukup rapat (warna coklat tua). Kejadian puting beliung 1 kali meliputi Kecamatan Pedan, Karangdowo, Wonosari, Karanganom, Klaten Tengah, Bayat, Prambanan dan Manisrenggo dengan tingkat vegetasi banyak pemukiman/lahan kosong (warna merah). Sedangkan Wilayah Kecamatan Kemalang dan Jatinom dengan tingkat vegetasi banyak sawah/tegalan (warna hijau muda).

Sebaran titik kejadian puting beliung di Kabupaten Klaten tahun 2018-2019 setelah di buat layer dengan klasifikasi kerapatan dan vegetasi secara umum berada pada wilayah yang tingkat kerapatan dan vegetasinya yang rendah, kepadatan pemukiman penduduk juga berpengaruh, sehingga semakin banyak wilayah terbuka dan kurang vegetasi merupakan salah satu faktor yang berpotensi untuk terjadi angin puting beliung, selain faktor suhu tinggi, tekanan udara dan awan kumulonimbus. 


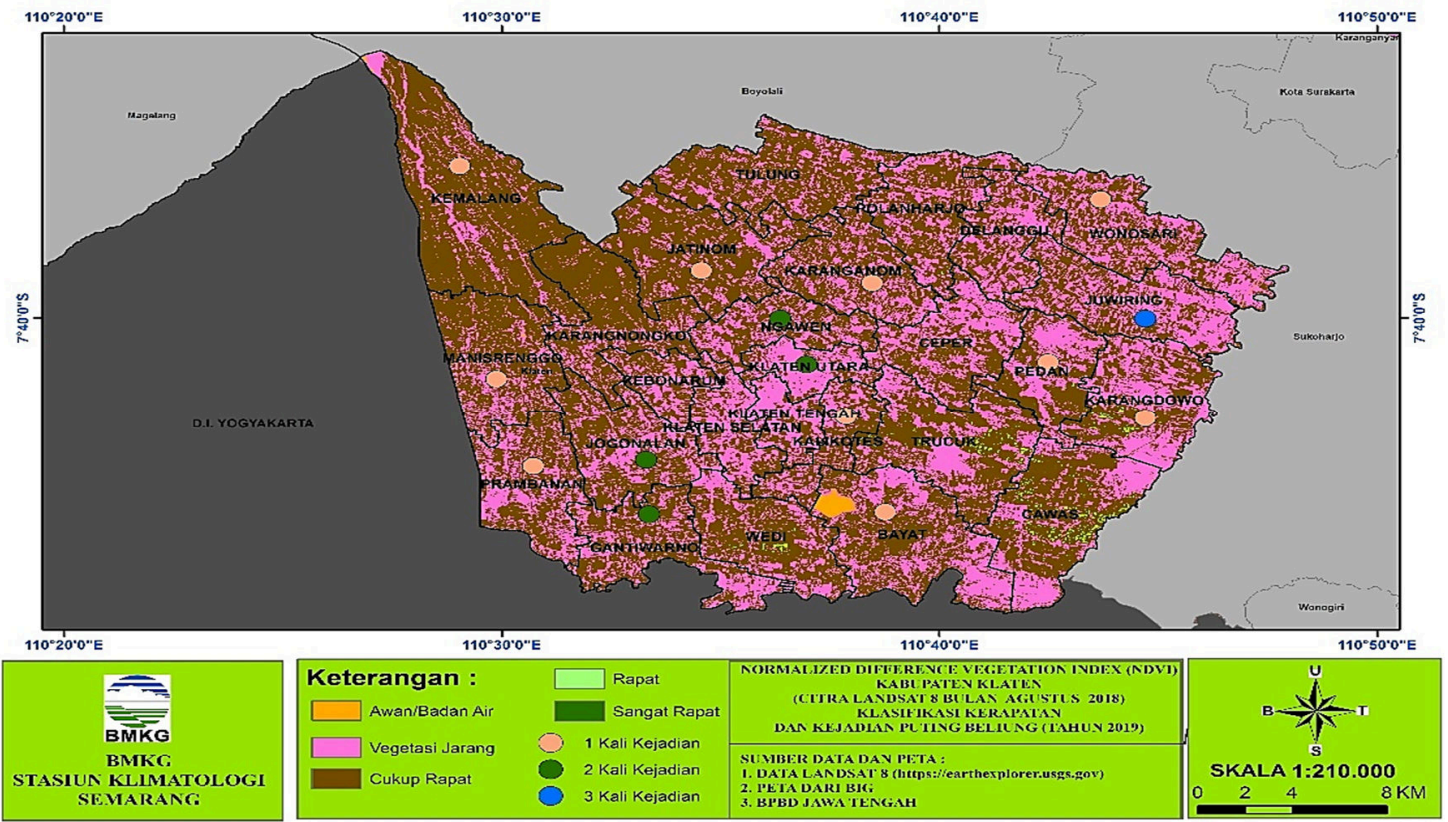

Gambar 11. Peta titik kejadian puting beliung layer dengan klasifikasi kerapatan di Kabupaten Klaten Tahun 2019.

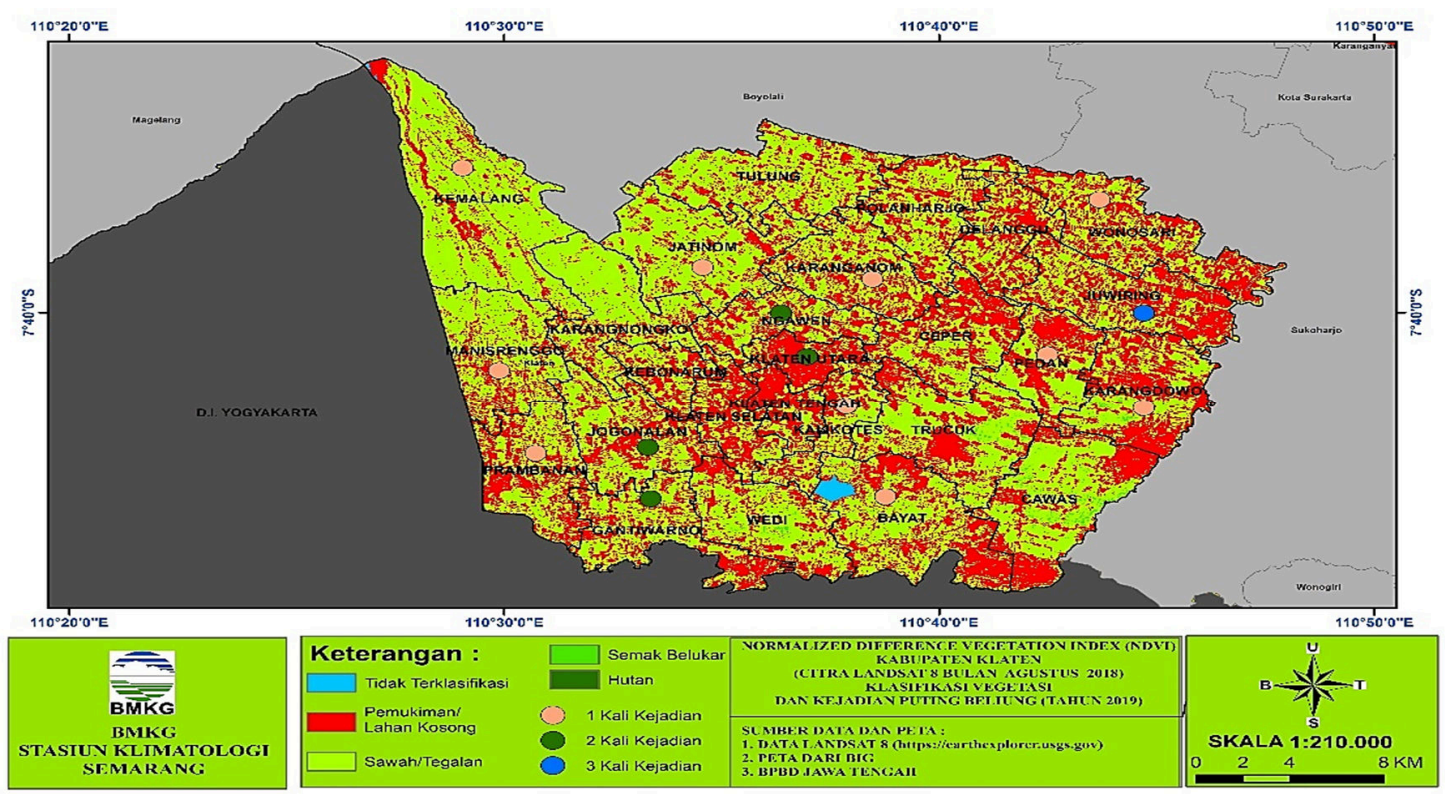

Gambar 12. Peta titik kejadian puting beliung layer dengan klasifikasi vegetasi di Kabupaten Klaten Tahun 2019.

\section{Kesimpulan}

A. Dengan melakukan analisa citra landsat 8 dengan klasifikasi kerapatan dan vegetasi serta titik kejadian puting beliung di wilayah Kabupaten Klaten didapat 3 kesimpulan yaitu :

1. Wilayah Kabupaten Klaten sesuai citra Landsat 8 tahun 2018 lebih sedikit vegetasi dengan kerapatan tinggi, yang lebih banyak adalah lahan terbuka seperti sawah/tegal dan pemukiman penduduk.

2. Kejadian puting beliung di wilayah Kabupaten Klaten berdasarkan data tahun 2018-2019 terjadi pada bulan Desember-April.

3. Dengan semakin sedikitnya vegetasi yang kerapatannya tinggi dan semakin meningkatnya pemukiman penduduk dan lahan terbuka, maka potensi puting beliung akan semakin meningkat selain karena faktor lain.

B. Dalam Penelitian ini hanya fokus pada deskripsi hubungan antara indeks kerapatan tanaman/vegetasi dengan potensinya puting beliung berdasarkan dari data BPBD Jawa Tengah. 


\section{Saran}

1. Perlu ditingkatkan penelitian lebih lanjut dengan melibatkan unsur cuaca/iklim seperti suhu udara, tekanan udara dan lain-lain.

2. Perlu dilakukan penelitian dengan metode numerik tentang hubungan antara indeks kerapatan tanaman/vegetasi dengan potensi puting beliung.

\section{Daftar Pustaka}

[1] Geografi dan Topografi Kabupaten Klaten. (2020, Juni 6). From https://klatenkab.go.id/geografi-dantopografi-kabupaten-klaten/.

[2] Lufilah, Siti Novianti., dkk. (2017). Pemanfaatan Citra Landsat 8 Untuk Analisis Indeks Vegetasi di DKI Jakarta, Jurnal Lanskap Indonesia, 9 (1). Retrieved from https://journal.ipb.ac.id.

[3] Putra H, Erwin (2010). Penginderaan Jauh dengan Er Mapper. Graha IImu, Yogyakarta.

[4] Hartono. (1998). Pengolahan Sampah Organik. Erlangga. Jakarta.

[5] Danoedoro, Projo. (1996). Pengolahan Citra digital Teori dan Aplikasinya dalam Bidang Penginderaan Jauh, Fakultas Geografi Universitas Gadjah Mada.

[6] Jensen JR.I.(1986). Introductory Digital Image Processing: A Remote Sensing Perspective. New Jersey: Prentice Hall Englewood Cliffs.

[7] Harsa, Hastuadi, dkk. (2011). Pemanfaatan SATAID Untuk Analisa Banjir dan Angin Puting Beliung: Studi Kasus Jakarta dan Yogyakarta. Jurnal Meteorologi dan Geofisika, 12(2):195-205

[8] Kambhampaty, Viswanath et all. (2014). A Short Term Tornado Prediction Model Using Satellite Imagery. First International Conference on Systems Informatics, Modelling and Simulation. IEEE Computer Society.

[9] Nurlambang, T., dkk. (2013, Oktober) Penanggulangan Bencana Cuaca Ekstrim di Indonesia. Prosiding Seminar Riset Kebencanaan. Retrieved from https://ppgt.ui.ac.id/wpcontent/uploads/62/2016/09/Triarko-dllPenanggulangan-Bencana_CuacaEktrim.pdf

[10] Putra, Kusuma Prayoga Basuki. (2015). Analisis Kerentanan Bangunan Terhadap Bencana Angin Puting Beliung di Kecamatan Tanon Kabupaten Sragen. Skripsi, Fakultas Geografi ,Surakarta, Universitas Muhammadiyah Surakarta.
[11] Amliana, Dit., dkk. (2016). Analisis Perbandingan Nilai NDVI Landsat 7 dan Landsat 8 Pada Kelas Tutupan Lahan (Studi Kasus: Kota Semarang, Jawa Tengah). Jurnal Geodesi UNDIP Semarang, 5 (1).

[12] Puslitbang BMKG. (2009). Kajian Cuaca Ekstrim di Wilayah Indonesia. Laporan Penelitian, Pusat Penelitian dan Pengembangan, Badan Meteorologi Klimatologi dan Geofisika, Jakarta.

[13] Huda, Diki Nurul. (2018, Februari). Analisis Kerapatan Vegetasi Untuk Area Permukiman Menggunakan Citra Satelit Landsat di Kota Tasikmalaya, https://www.researchgate.net/publication/3 23346324. .

[14] PPID BPBD Provinsi Jawa Tengah. Laporan Bencana Puting Beliung Retrieved from http://bpbd.jatengprov.go.id/category/lapor an bencana/.

[15] Nurjani, Emilya., dkk. (2013, November). Kajian Bencana Angin Ribut di Indonesia Periode 1990-2011: Upaya Mitigasi Bencana, $11 \quad$ (2) Retrived from https://journal.uny.ac.id/index.php/geomedi a/article/view/3451/2932.

[16] Siswanto and Supari. (2012). Identifikasi Kondisi Awal Peristiwa Puting Beliung di Pangkal Pinang. Jurnal Widyariset, 15 (3): 599-610. 